\title{
Epidemiology of Myxosporean Infections in Economically Important and Dietary Freshwater Fishes in the Sudano-Guinean Zone of Cameroon
}

\section{FONKWA G $^{1,3,4 *}$, KOUAM KM ${ }^{2}$, TOMEDI EM ${ }^{1}$, TCHUINKAM $^{3}$ and TCHOUMBOUE ${ }^{4}$}

${ }^{1}$ Laboratory of Aquaculture and Demography of Aquatic Resources, Institute of Fisheries and Aquatic Sciences, Department of Aquaculture, University of Douala, Cameroon

${ }^{2}$ Physiology and Animal Health Research Unit, Department of Animal Production, Faculty of Agronomy and Agricultural Science, University of Dschang, Cameroon

${ }^{3}$ Vector Borne Diseases Laboratory of the Applied Biology and Ecology Research Unit, Department of Animal Biology, Faculty of Science, University of Dschang, Cameroon

${ }^{4}$ Applied Hydrobiology and Ichthyology Research Unit, Department of Animal Production, Faculty of Agronomy and Agricultural Science, University of Dschang, Cameroon

*Corresponding author: FONKWA Georges, Laboratory of Aquaculture and Demography of Aquatic Resources, Institute of Fisheries and Aquatic Sciences, Department of Aquaculture, University of Douala, P.0. Box 7236 Douala, Cameroon, Tel: (+237) 6742989 24; Email: fonkwageorges@gmail.com

\section{Abstract}

The epidemiology of Myxosporean infections was carried out from May 2016 to May 2017. Thus, 857 Teleosts (350 Oreochromis niloticus, 305 Barbus callipterus, 118 Hemichromis fasciatus and 84 Clarias gariepinus) from the Mayo -Banyo Division in the Sudano-guinean zone of Cameroon were sampled and the prevalence of myxosporean infections was determined after examination of fishes. A total of 21 myxosporean species belonging to four genera (Myxobolus, Myxidium, Henneguya and Thelohanellus) were recorded. The genus Myxobolus exhibited the highest prevalence $(37.11 \%)$ and Henneguya $(0.35 \%)$ the lowest. All the four fish species were infected with the genus Myxobolus with the highest $(\mathrm{P}<0.001)$ prevalence in 0 . niloticus (45.43\%) and B. callipterus (45.90\%). A total of 325 fishes were infected (37.92\%). B. callipterus (48.20\%) followed by 0 . niloticus $(45.43 \%)$ were the most infected $(\mathrm{P}<0.001)$ compared to $C$. gariepinus $(9.52 \%)$ and $H$. fasciatus $(9.32 \%)$. The prevalence of parasite species was not correlated ( $\mathrm{P}>0.05)$ with the condition factor and fish size except that of Myxobolus tilapiae which was positively correlated with $O$. niloticus size $(\mathrm{r}=+0.17 ; \mathrm{P}<0.01)$. Males were significantly $(\mathrm{P}<0.001)$ more infected than females in $H$. fasciatus only. The overall prevalence was insignificantly $(\mathrm{P}>0.05)$ higher in the dry season than in the rainy season. Out of 12 parasitized organs, $O$. niloticus and $C$. gariepinus exhibited the highest (10 organs) and lowest ( 3 organs) number of infected organs respectively. This study provided some baseline data useful in myxosporean infections prevention and control in fishes from Adamawa-Cameroon.

Keywords: Fish; Myxosporean; Infections; Prevalence; Cameroon

\section{Introduction}

Fish represents about $51 \%$ of animal proteins intake in Africa [1]. In Cameroon particularly, the national annual production of fishes is only 180, 000 tons versus a yearly demand of 400, 000 tons. As a result, a supplementary quantity of 250,000 tons is imported every year corresponding to CFA F 200 billions expenditure [2]. This situation is paradoxical 
since the Sudano-guinean zone of the country is particularly endowed with a great hydrographic potential. This includes the MAPE dam in the Adamawa region of Cameroon which is an important fish reservoir. Four fish species are commonly found in this dam namely Oreochromis niloticus, Hemichromis fasciatus, Clarias gariepinus and Barbus callipterus, all of economic and dietary importance. Unfortunately, from 1990 to 2015, a $15 \%$ drop of the annual fish production was recorded [2] due to a number of constraints. These constraints limiting fish productions include not only climate change [3] and overfishing, but also parasitic diseases one of is Myxosporidiosis [4].

Myxosporidiosis impedes fish growth [5] and reproduction [6] and is involved in epizootics responsible for massive fish deaths in farms and hatcheries [7,8]. Epidemiological studies are a prerequisite to myxosporidiosis prevention and control because it provides both qualitative and quantitative data about the spatio-temporal spread of the infection as well as associated risk factors. This study aimed at assessing the prevalence and some epidemiological aspects of myxosporean infections in fishes in the Sudanoguinean zone of Cameroon in order to provide baseline data for their effective prevention and control.

\section{Materials and Methods}

\section{Study Area and Period}

Fishes were collected from May 2016 to May 2017 in MAPE dam (Figure 1) built on MAPE River, a tributary of Mbam River, Bankim subdivision $\left(6^{\circ} 00^{\prime}-6^{\circ} 20^{\prime} \mathrm{NL} / 11^{\circ} 20^{\prime}\right.$ $11^{\circ} 40^{\prime}$ EL), Mayo-Banyo Division and Adamawa Region of Cameroon. The average altitude is about $724 \mathrm{~m}$. The soil is composed of clay and sand. Climate is of the tropical Sudano-guinean type with two seasons: a long rainy season running from March to November and a short dry season from November to March. The annual average temperature is about $23^{\circ} \mathrm{C}$ and the rainfall varies between 1500 and 2000 $\mathrm{mm}$ [9].

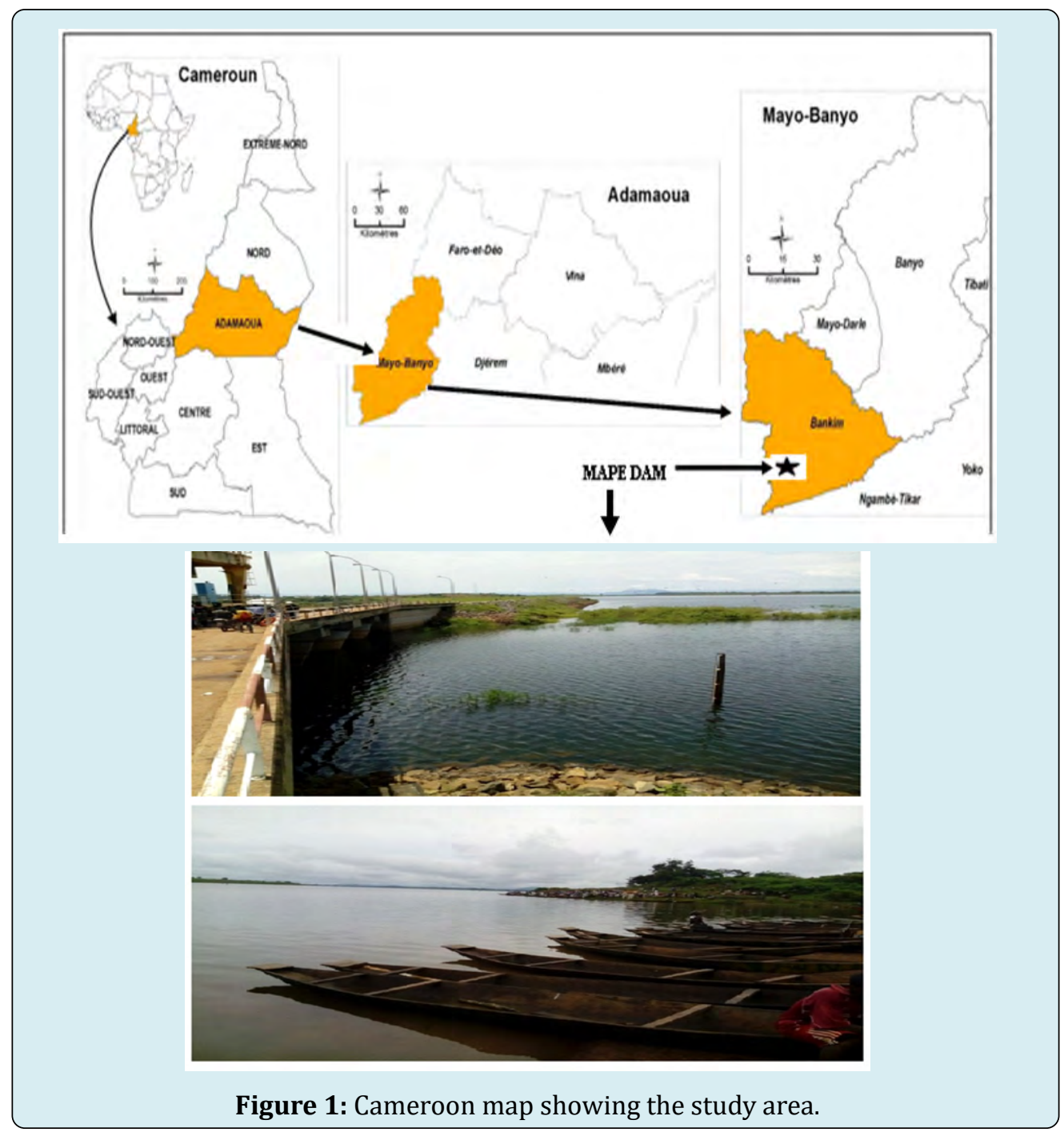

FONKWA G, et al. Epidemiology of Myxosporean Infections in Economically Important and Dietary Freshwater Fishes in the Sudano-Guinean Zone of Cameroon. Int J Oceanogr Aquac 


\section{International Journal of Oceanography \& Aquaculture}

Fish Sampling and Characteristics of Samples

Fishes (Figure 2) were purchased monthly from fishermen. They were captured both at day and night using fish nets and fishing canes. Fish specimens were immediately stored in a vial containing $10 \%$ formalin solution and transported to the laboratory for examination. The characteristics of fish samples are illustrated in Table 1.

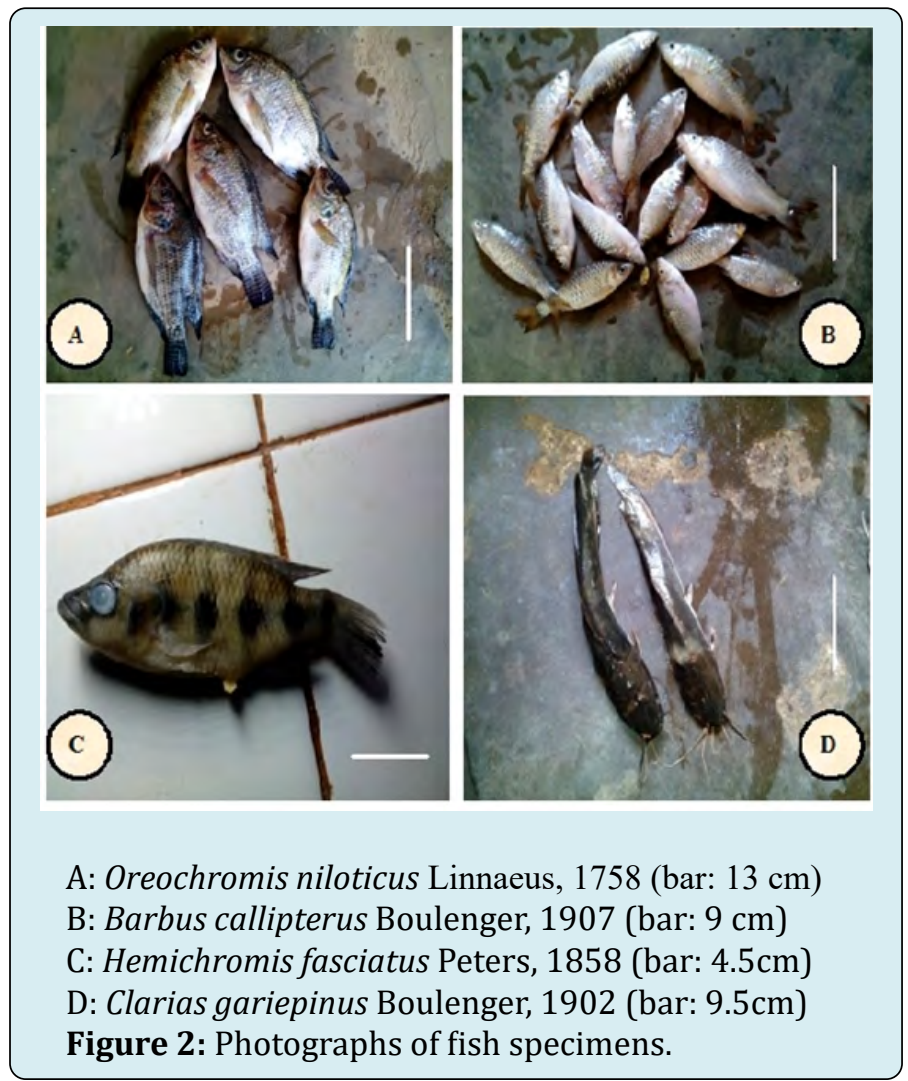

\begin{tabular}{|c|c|c|c|c|c|c|c|c|c|}
\hline \multirow{2}{*}{ Host } & \multirow[b]{2}{*}{ Sex } & \multicolumn{4}{|c|}{ Class size $(\mathrm{mm})$} & \multirow[b]{2}{*}{ Total } & \multicolumn{2}{|c|}{ Seasons } & \multirow[b]{2}{*}{$\operatorname{MSL}(\mathbf{m m})$} \\
\hline & & {$[50-100]$} & ]100-150] & ]150-200] & [200 - 250] & & Rainy & Dry & \\
\hline \multirow{3}{*}{$\begin{array}{l}\text { Oreochromis } \\
\text { niloticus }\end{array}$} & $\hat{0}$ & 134 & 76 & 8 & 1 & 219 & 129 & 90 & \\
\hline & $q$ & 95 & 34 & 2 & 0 & 131 & 68 & 63 & \\
\hline & $\hat{\theta}+q$ & 229 & 110 & 10 & 1 & 350 & 197 & 153 & $97.13(51-240)$ \\
\hline \multirow{3}{*}{$\begin{array}{l}\text { Hemichromis } \\
\text { fasciatus }\end{array}$} & $\hat{0}$ & 57 & 3 & 0 & 0 & 60 & 39 & 21 & \\
\hline & $q$ & 55 & 3 & 0 & 0 & 58 & 39 & 19 & \\
\hline & $\hat{\partial}+q$ & 112 & 6 & 0 & 0 & 118 & 78 & 40 & $30.10(54-150)$ \\
\hline \multirow{3}{*}{$\begin{array}{c}\text { Clarias } \\
\text { gariepinus }\end{array}$} & $\hat{0}$ & 0 & 17 & 16 & 11 & 44 & 19 & 25 & \\
\hline & q & 0 & 19 & 12 & 9 & 40 & 17 & 23 & \\
\hline & $\hat{\theta}+q$ & 0 & 36 & 28 & 20 & 84 & 36 & 48 & $32.28(110-250)$ \\
\hline \multirow{3}{*}{$\begin{array}{c}\text { Barbus } \\
\text { callipterus }\end{array}$} & $\hat{0}$ & 156 & 3 & 0 & 0 & 159 & 79 & 80 & \\
\hline & $q$ & 146 & 0 & 0 & 0 & 146 & 63 & 83 & \\
\hline & $\hat{s}+q$ & 302 & 3 & 0 & 0 & 305 & 142 & 163 & $28.87(52-110)$ \\
\hline \multirow{4}{*}{ Total } & $\hat{0}$ & 347 & 99 & 24 & 12 & 482 & 266 & 216 & \\
\hline & $q$ & 296 & 56 & 14 & 9 & 375 & 187 & 188 & \\
\hline & $\hat{o}+q$ & 643 & 155 & 38 & 21 & 857 & 453 & 404 & $47.57(51-250)$ \\
\hline & $\%$ & $75.03 \%$ & $18.09 \%$ & $4.43 \%$ & $2.45 \%$ & $100 \%$ & $52.86 \%$ & $47.18 \%$ & \\
\hline
\end{tabular}

Mean Standard Length (MSL) is followed in bracket by minimum-maximum values; $\delta$ : male; $:$ : female Table 1: Characteristics of fish samples. 


\section{Fish Examination and Myxosporeans Identification}

Fishes were identified as described by Stiassny, et al. [10] and examined according to Abakar [4]. Standard and total lengths of fishes were measured to the closest millimeter using a slide caliper of stainless brand. Fishes were weighed using Sartorius electronic scale of $0.01 \mathrm{~g}$ accuracy and the sex- determined after dissection. The fish condition factor (K) was calculated using the following formula by Charles and Alan [11]:

$$
K=\frac{\text { Fishbodyweight }(\mathrm{g})}{[\text { Total Length }]^{3}(\mathrm{~cm})} \times 100
$$

The condition factor expresses the health status or the fish well-being at a given time [12]. As fish grow their condition factor or well fare increases [13]. The fish's heath is good if $\mathrm{k}>1$ and poor when $\mathrm{k}<1$ [14]. The condition factor varies according to fish age, sex, season, the stage of development of the reproductive organs, the fullness of gut, type of food consumed, amount of fat reserve and degree of muscular development [11].

External organs (fins, skin, scales and eyes) and internal organs (gills, spleen, kidneys, intestines, gall bladder, stomach and gonads) were examined with naked eyes, then with stereoscopic microscope using the $10 \mathrm{X}$ lens to look for the cysts. Three smears of the kidneys, spleen and gonads were made per organ (anterior, medium and posterior regions) and examined at a total magnification of $1000 \mathrm{X}$ with a light microscope for presence of spores.
Cysts were crushed between a slide and a cover glass in a drop of distilled water and their contents were identified with the light microscope using the 100X lens. Spores were fixed and stained with methanol and May-Grünwald-Giemsa respectively and photographed with a digital camera (Canon Ixus brand). Myxosporean species were measured with a calibrated ocular micrometer as recommended by Lom and Arthur [15] and were morphologically identified. The identification keys provided by Fomena and Bouix [16], Lom and Dyková $[17,18]$, Eiras, et al. [19,20] were equally used. Myxospores were also compared with recently published worldwide reports

\section{Epidemiological Parameter and Statistical Analysis}

The epidemiological parameter i.e. the prevalence (Pr) of infection expressed as a percentage was defined as the number of host species infected by a given parasite species divided by the number of fish examined [21]. The prevalence was classified as very low $(\operatorname{Pr}<10 \%)$, low $(10 \% \leq \operatorname{Pr} \leq 50 \%)$ and high ( $\mathrm{Pr}>50 \%)$ corresponding to scarce, intermediate and principal parasite species respectively. This classification was adapted from Valtonen, et al. [22].

The comparison of prevalence was performed using the Chi-square $\left(\mathrm{X}^{2}\right)$ test and the Spearman correlation coefficient " $r$ " was determined. The error probability was $\mathrm{P}<0.05$ and the Graph Pad Prism 5 software was used for analysis.

\section{Results}

The results are illustrated in Tables $2 \& 3$ and Figures 3 - 12 .

\begin{tabular}{|c|c|c|c|c|}
\hline \multirow{2}{*}{} & \multicolumn{4}{|c|}{ Fish species } \\
\cline { 2 - 5 } & O. niloticus & H. fasciatus & C. gariepinus & B. callipterus \\
\hline $\mathrm{r}$ & 0.17 & 0.06 & 0.00 & 0.07 \\
\hline $\mathrm{P}$ & 0.05 & 0.556 & 0.940 & 0.219 \\
\hline
\end{tabular}

$\mathrm{r}$ : correlation coefficient ; P : error probability

Table 2: Correlation between the prevalence and fish condition factor $(\mathrm{K})$.

\begin{tabular}{|c|c|c|c|c|c|c|c|c|c|c|c|c|}
\hline & \multicolumn{10}{|c|}{ Infection sites } \\
\hline Parasite species & Eyes & Operculum & Skin & Fins & Gills & Kidneys & Liver & Spleen & Intestine & Ovaries & $\mathbf{X}^{2}$ & P \\
\hline $\begin{array}{c}\text { Myxobolus } \\
\text { camerounensis }\end{array}$ & 2.28 & 1.43 & 1.43 & 2 & 0.86 & 3.14 & 0 & 0 & 0 & 0 & 36.54 & $<0.001$ \\
\hline $\begin{array}{c}\text { Myxobolus } \\
\text { israelensis }\end{array}$ & 0 & 0.57 & 0.29 & 0 & 0 & 8.57 & 0 & 0.86 & 0 & 0 & 227.6 & $<0.001$ \\
\hline $\begin{array}{c}\text { Myxobolus } \\
\text { heterosporus }\end{array}$ & 0.57 & 0 & 0 & 0 & 0 & 8 & 0.57 & 0.57 & 0 & 0 & 209.3 & $<0.001$ \\
\hline Myxobolus agolus & 0 & 0 & 0 & 0 & 0 & 5.43 & 0.29 & 0 & 0 & 0 & 161.9 & $<0.001$ \\
\hline Myxobolus tilapiae & 0 & 0 & 0.29 & 0 & 0.57 & 14 & 0.57 & 0.29 & 0 & 0 & 398.1 & $<0.001$ \\
\hline
\end{tabular}




\begin{tabular}{|c|c|c|c|c|c|c|c|c|c|c|c|c|}
\hline $\begin{array}{c}\text { Myxobolus } \\
\text { brachysporus }\end{array}$ & 0 & 0 & 0 & 0 & 0 & 11.14 & 0.57 & 0.29 & 0.57 & 0 & 316 & $<0.001$ \\
\hline Myxobolus kainjiae & 0 & 0 & 0 & 0 & 0 & 0 & 0 & 0 & 0 & 4.29 & 135.6 & $<0.001$ \\
\hline $\begin{array}{c}\text { Myxobolus } \\
\text { tchadanayei }\end{array}$ & 0 & 0 & 0.29 & 0 & 0 & 3.14 & 0.29 & 0 & 0.29 & 0 & 69.97 & $<0.001$ \\
\hline Myxobolus mapei & 0 & 0 & 0 & 0 & 0 & 2.86 & 0.57 & 0 & 0 & 0 & 74.92 & $<0.001$ \\
\hline Myxobolus ellipsoides & 0 & 0 & 0 & 0 & 0 & 4.57 & 0.29 & 0 & 0 & 0 & 134.8 & $<0.001$ \\
\hline $\begin{array}{c}\text { Myxobolus } \\
\text { pseudodispar }\end{array}$ & 0 & 0 & 0 & 0 & 0 & 2 & 0 & 0 & 0 & 0 & 63.13 & $<0.001$ \\
\hline $\begin{array}{c}\text { Myxobolus } \\
\text { pharyngeus }\end{array}$ & 0 & 0 & 0 & 0 & 0 & 0.85 & 0 & 0 & 0 & 0 & 27.02 & $<0.01$ \\
\hline Total & 2.85 & 2 & 2.29 & 2 & 1.43 & 36.57 & 2 & 1.43 & 0.86 & 4.29 & 719.6 & $<0.001$ \\
\hline $\mathrm{X}^{2}$ & 54.62 & 37.4 & 32.4 & 88.17 & 26.02 & 140.9 & 9.75 & 18.75 & 10 & 165.6 & & \\
\hline $\mathrm{P}$ & $<0.001$ & $<0.001$ & $<0.001$ & $<0.001$ & $<0.01$ & $<0.001$ & 0.553 & 0.066 & 0.53 & $<0.001$ & & \\
\hline
\end{tabular}

Table 3: Prevalence of parasite species as a function of infection sites in 0 . niloticus.

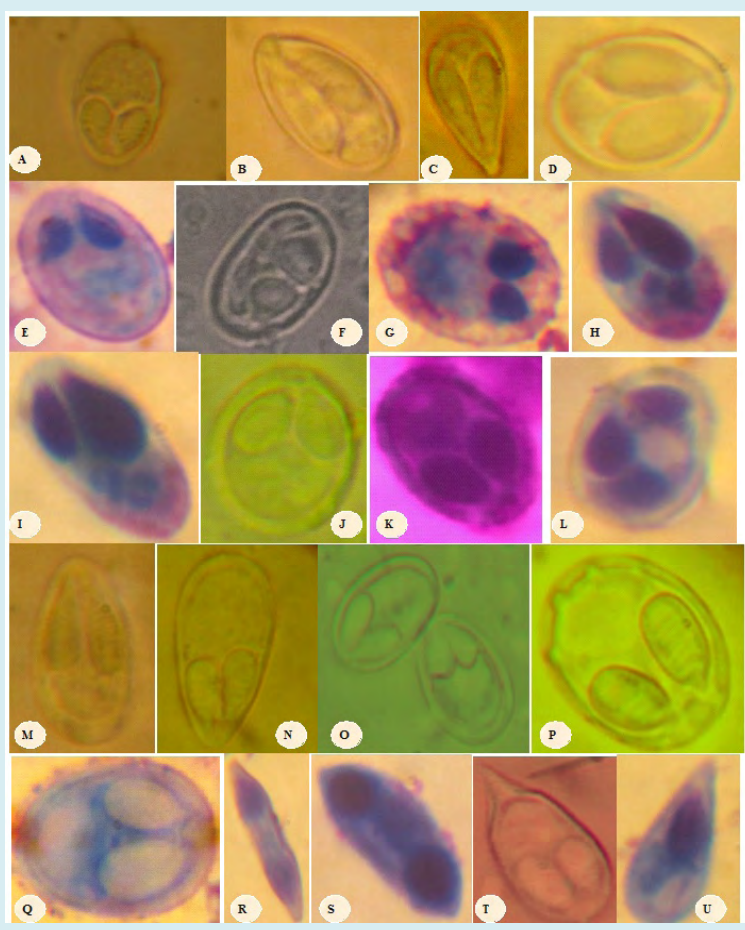

A: Myxobolus camerounenis Fomena et al.,1993 (x1500)

B : Myxobolus israelensis Landsberg, 1985(x1800)

C : Myxobolus heterosporus Baker, 1963 (x1500)

D : Myxobolus agolus Landsberg, 1985(x1500)

E : Myxobolus tilapiae Abolarin, 1974 (x1400)

F : Myxobolus brachysporus Baker, 1963(x1500)

G: Myxobolus kainjiae Obiekezie and Okaeme, 1990 (x1800)

H : Myxobolus tchadanayei Abakar et al., 2006 (x1300)

I : Myxobolus mapei Fonkwa et al.,2017 (x1500)

J : Myxobolus muelleri Bütschli,1882 (x 1600)

K: Myxobolus ellipsoides Thelohan, 1982 (x 1500)
L: Myxobolus pseudodispar Gorbunova, 1936 ( x 1600)

M: Myxobolus pharyngeus Parker et al., 1971 (x 1600)

N: Myxobolus tchoumbouei Fonkwa et al., 2017 (x1200)

0: Myxobolus umidus Carriero et al., 2013 (x1500)

P: Myxobolus sessabai Lekeufack et al., 2017(x1200)

Q: Myxobolus ngassami Lekeufack et al., 2017 (x1300)

R: Myxidium petrocephali Fomena et Bouix, 1986 (x1200)

S:Myxidium barbatulae Cépède, 1906 (x 1800)

T: Henneguya ntemensis Fomena et Bouix, 1996 (x 1800)

U: Thelohanellus valeti Fomena et Bouix, 1987 (x1700)

Figure 3: Spore micrographs of Myxosporeans found in fishes in MAPE dam, Adamawa-Cameroon. 


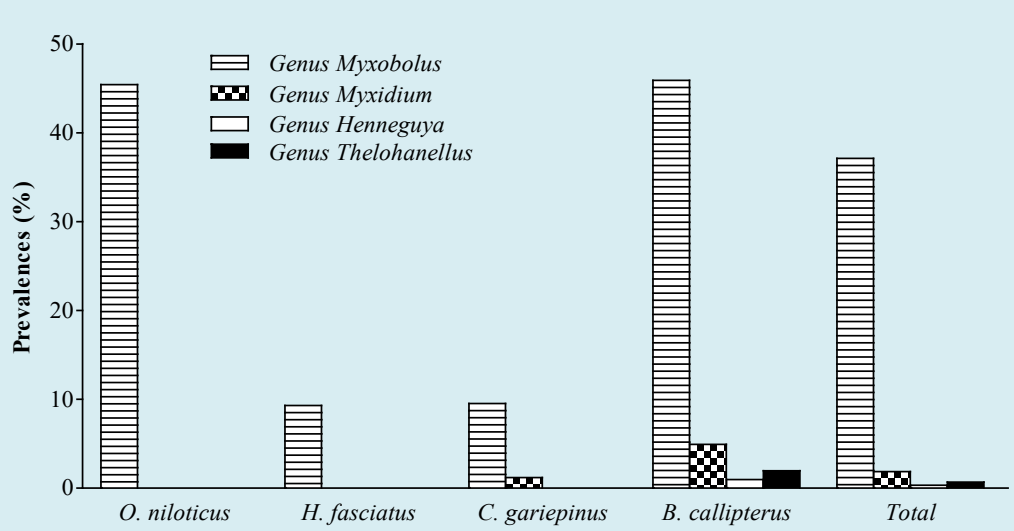

Figure 4: Prevalence of Myxosporeans genera.

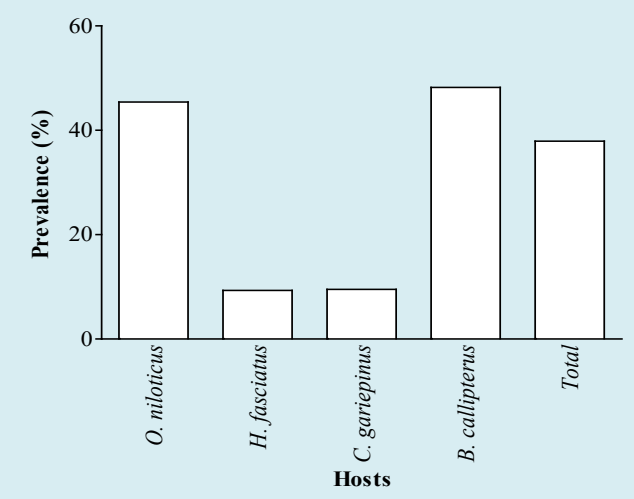

Figure 5: Prevalence of infection as a function of hosts.

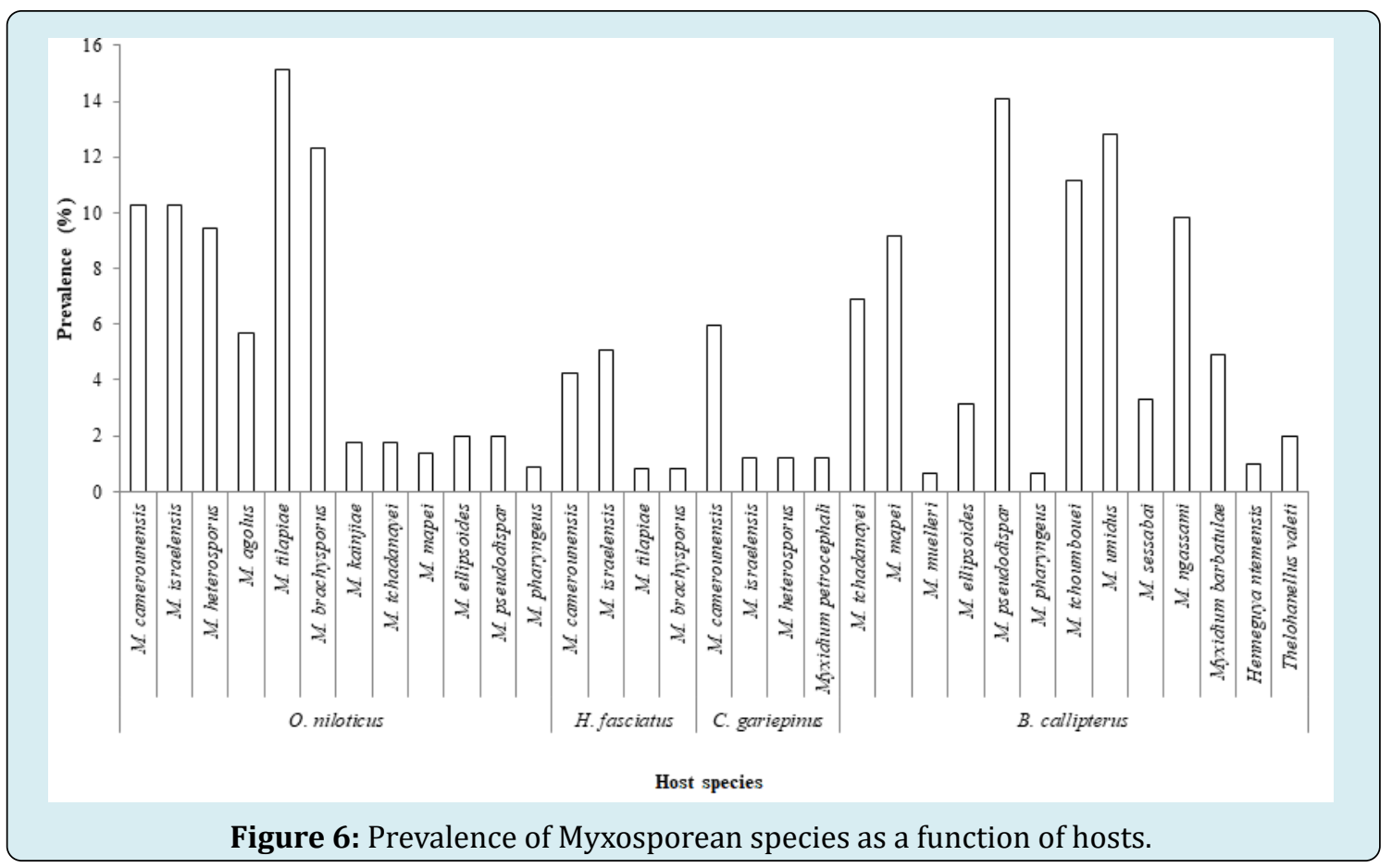



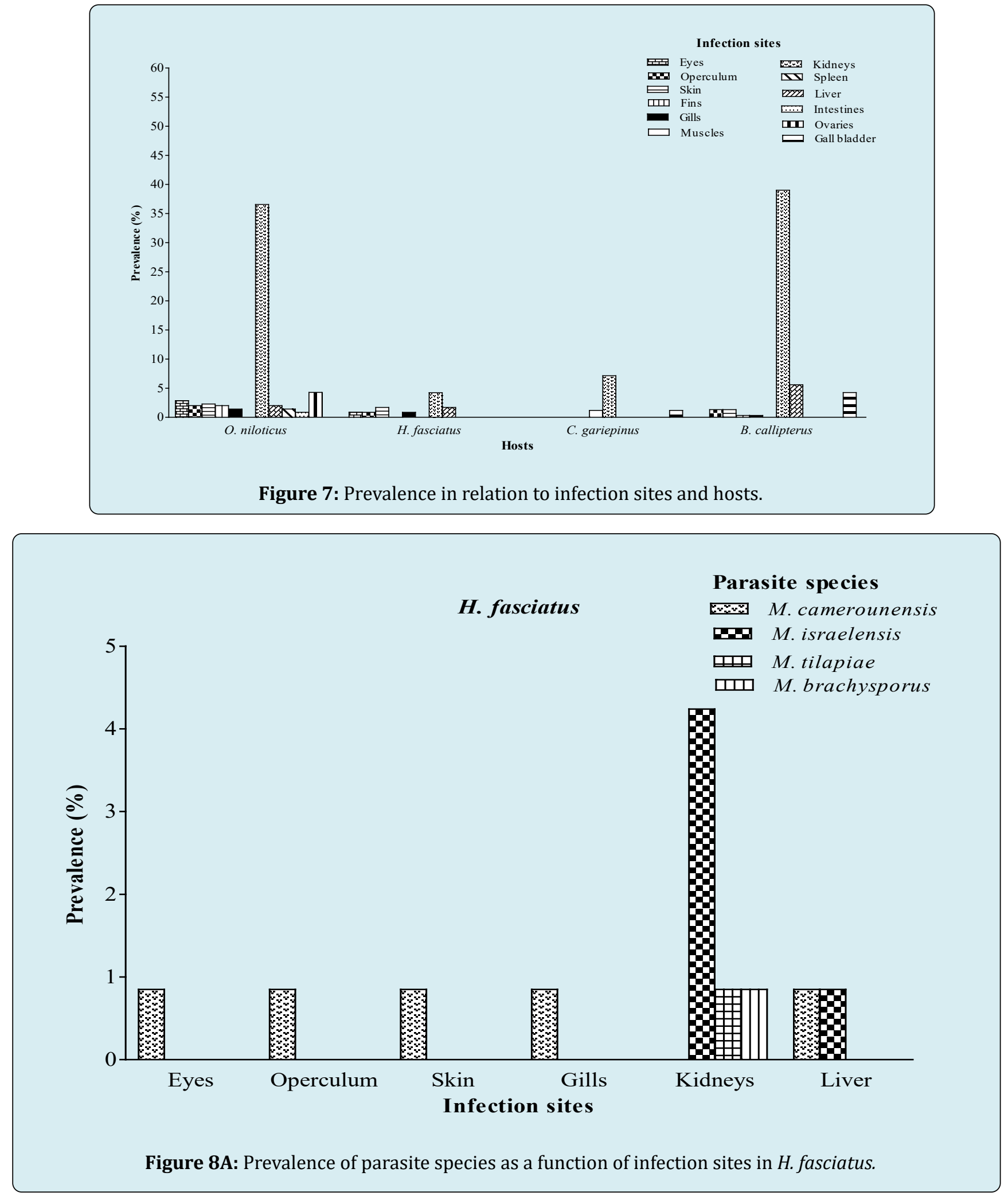


\section{C. gariepinus}

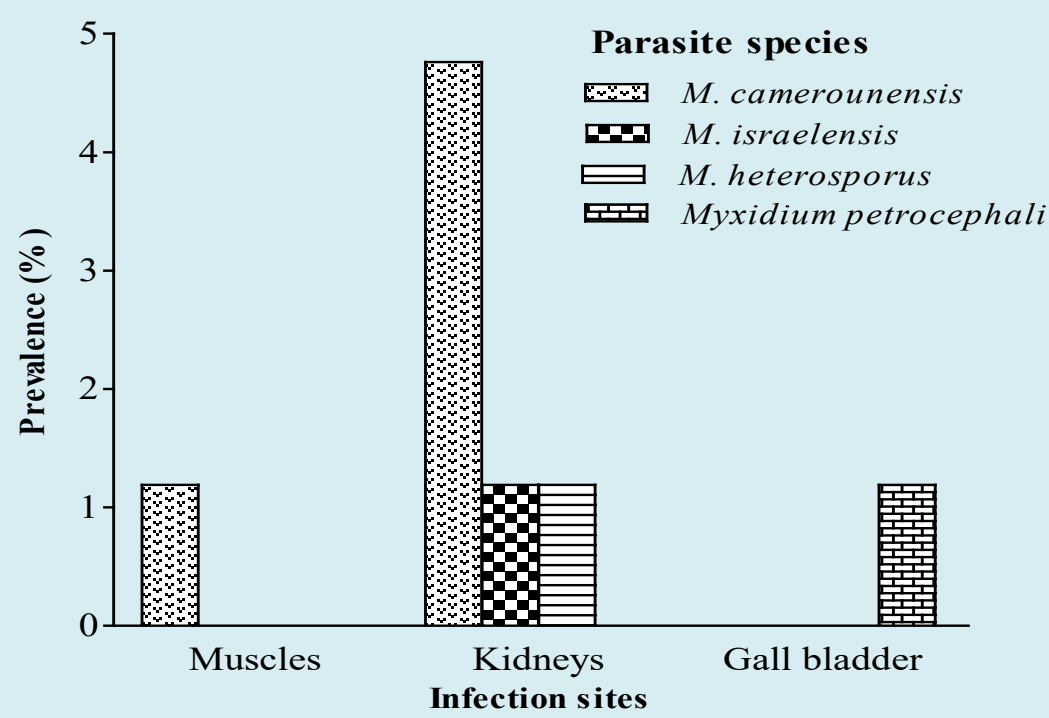

Figure 8B: Prevalence of parasite species as a function of infection sites in C. gariepinus.

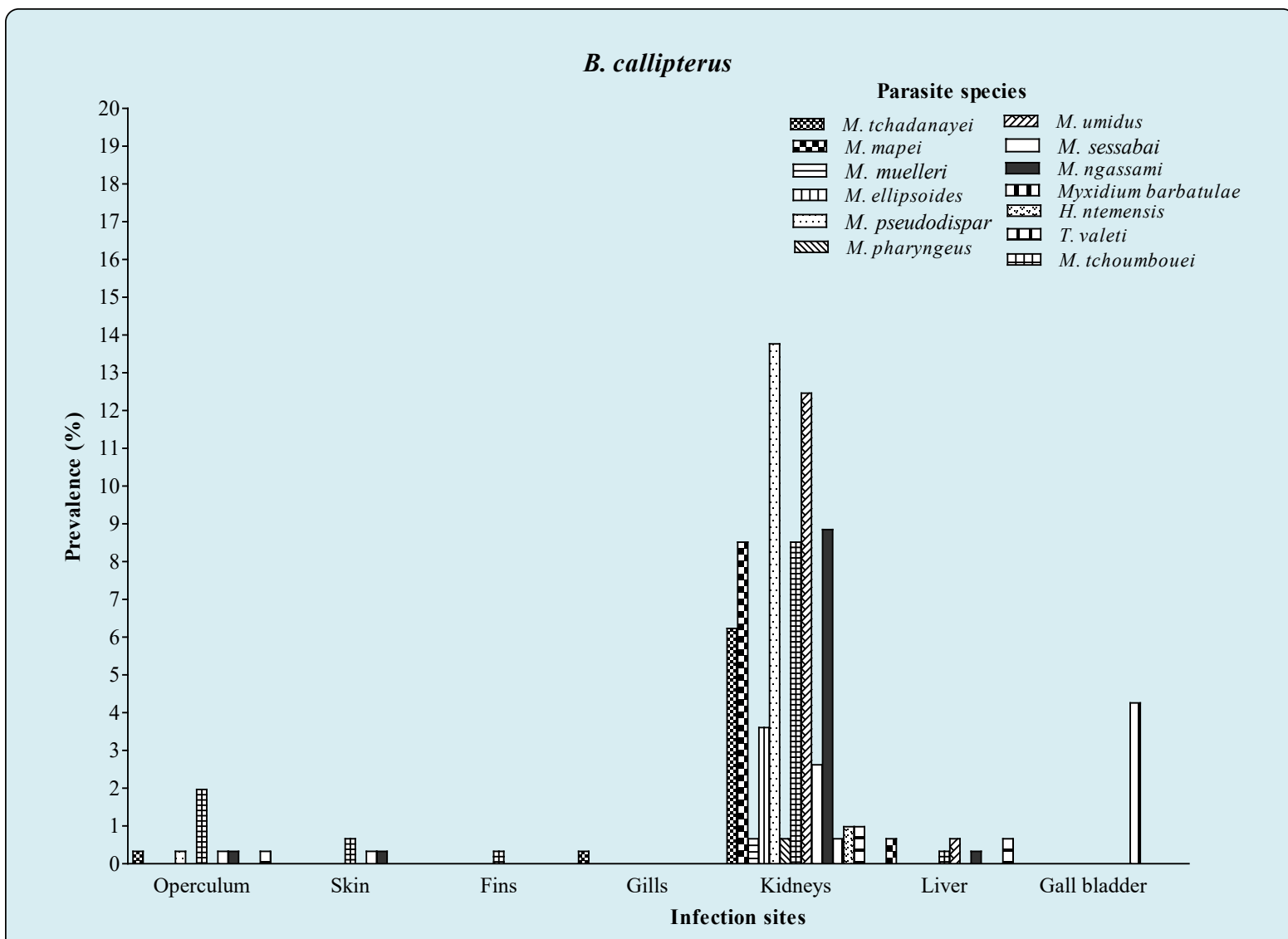

Figure 8C: Prevalence of parasite species as a function of infection sites in B. callipterus. 

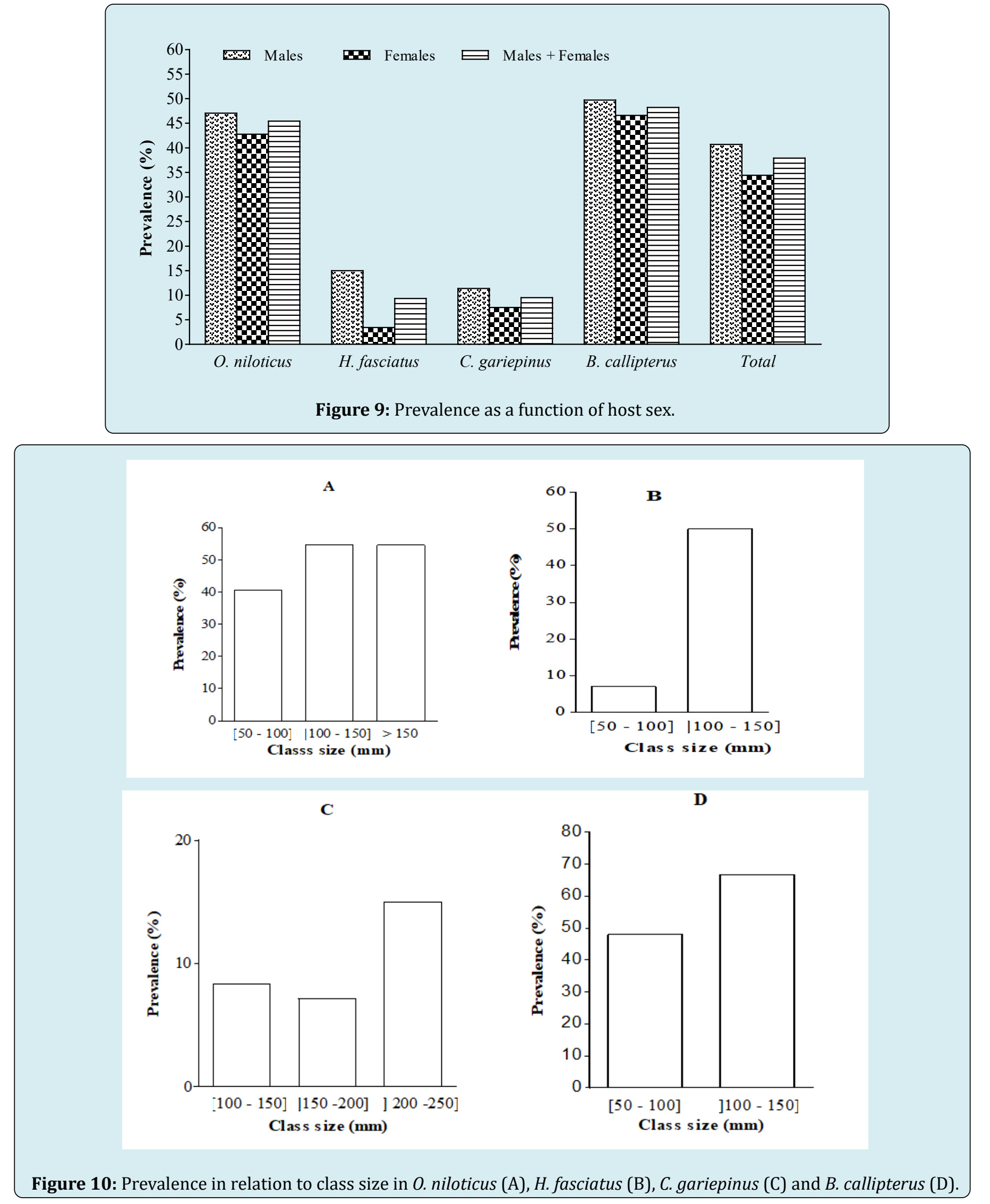


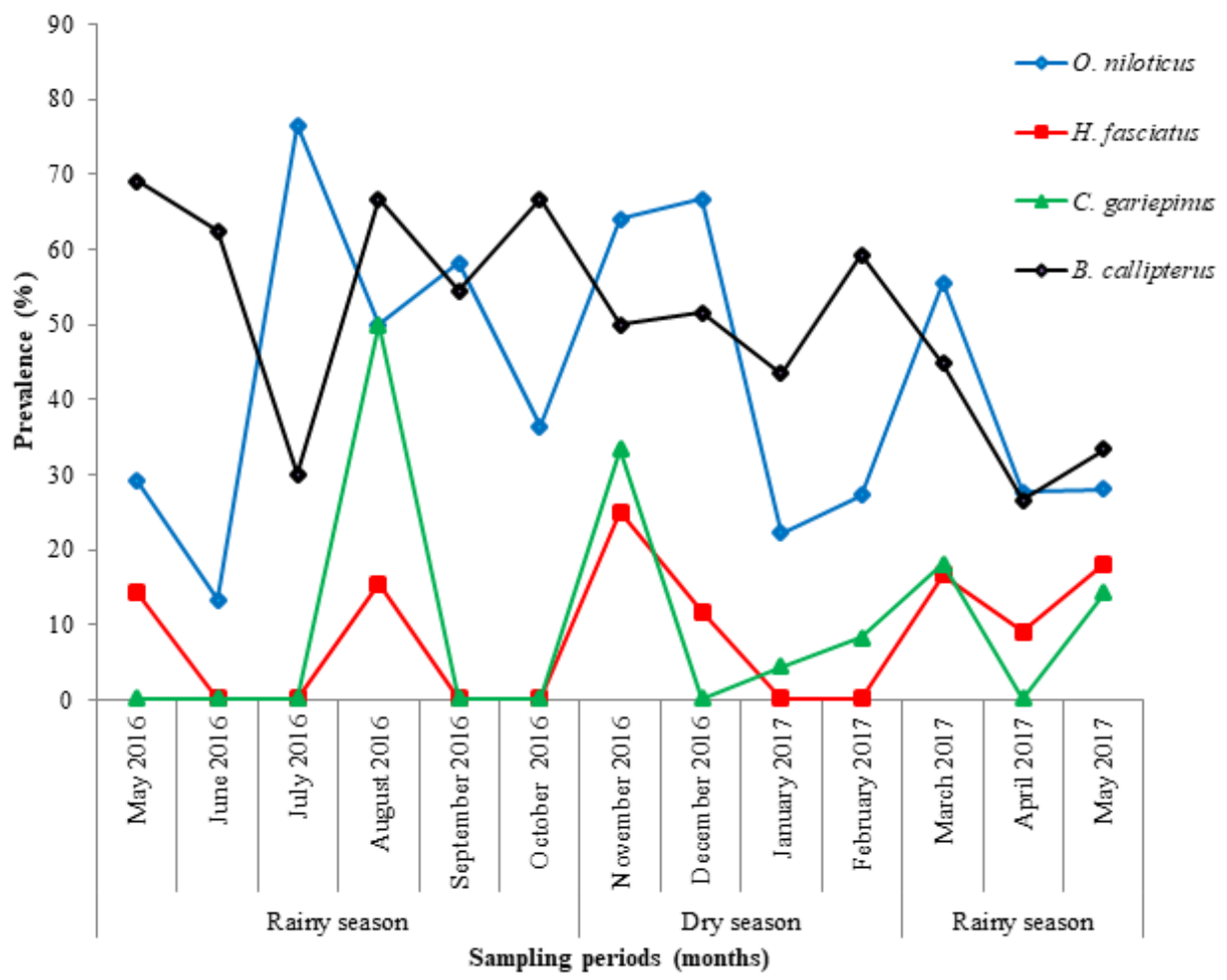

Figure 11: Monthly related prevalence of infection as a function of fish species.

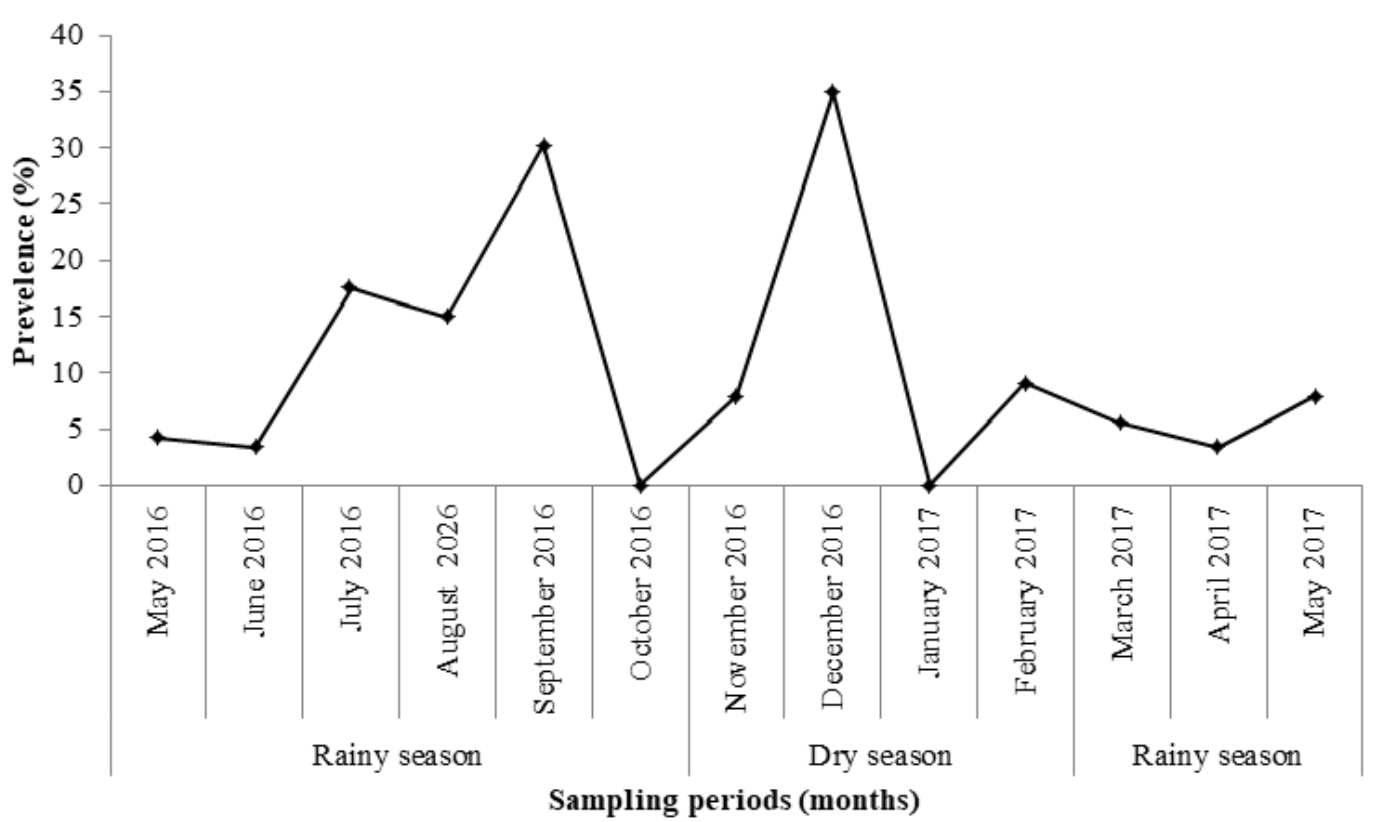

Figure 12: Monthly related prevalence of Myxobolus tilapiae in O. niloticus. 


\section{Prevalence of Myxosporeans Genera}

The myxosporeans fauna of fishes (Figure 3) was composed of 21 species belonging to the genera Myxobolus (17 species), Myxidium (2 species), Henneguya (1 species) and Thelohanellus (1 species). The prevalence of myxosporeans genera as illustrated in Figure 4 reveals that irrespective of the host species, the highest $\left(\mathrm{X}^{2}=58\right.$; $\mathrm{P}<0.001)$ infection rate $(37.11 \%)$ was recorded for the genus Myxobolus. On the contrary the less prevalent genera were in the decreasing order of infection rate Myxidium (1.87\%), Thelohanellus (0.70\%) and Henneguya (0.35\%). Moreover, Myxobolus spp infected all host species with the highest and significant prevalence $\left(\mathrm{X}^{2}=87.00 ; \mathrm{P}<0.001\right)$ in B. callipterus $(45.90 \%)$ and 0 . niloticus $(15.43 \%)$. The genus Myxidium was only found in two fish species namely C. gariepinus and B. callipterus with low prevalence i.e. 1.19 and $4.92 \%$ respectively. In addition, Henneguya and Thelohanellus were specific to a single host (B. callipterus). Meanwhile, the genus Myxobolus infected two host species namely $O$. niloticus and $H$. fasciatus. B. callipterus was the sole host to be infected by all the four myxosporeans genera.

\section{Fish Species as a Risk Factor}

As shown in Figure 5, all the four fish species were infected and the overall prevalence was $37.92 \%$ regardless of the fish species. The prevalence varied very remarkably with host species $\left(\mathrm{X}^{2}=92.00 ; \mathrm{P}<0.001\right)$. Although $B$. callipterus seemed to be more infected (48.20\%) than $O$. niloticus (45.43\%), no significant difference $\left(\mathrm{X}^{2}=0.50 ; \mathrm{P}\right.$ $=0.479$ ) was found between prevalence. Furthermore, $H$. fasciatus was the less infected fish $(9.32 \%)$.

\section{Host Related Prevalence of Myxosporean Infection}

The host related prevalence of myxosporean infection (Figure 6) reveals that parasite species were scarce or intermediate. B. callipterus and $O$. niloticus harbored more myxosporean species (13 and 12 respectively) than $H$. fasciatus and $C$. gariepinus, each of them being infected by four species. In $O$. niloticus, the prevalence significantly $\left(\mathrm{X}^{2}=118.80 ; \mathrm{P}<0.001\right)$ ranged from 0.86 to $15.14 \%$ for M. pharyngeus and M. tilapiae respectively. As for B. callipterus, M. pseudodispar exhibited the highest prevalence $\left(\mathrm{X}^{2}=145.90 ; \mathrm{P}<0.001\right)$ while $M$. muelleri and M. pharyngeus were the least occurring $(0.65 \%)$. Although the parasites prevalence did not vary significantly in $H$. fasciatus and C. gariepinus, Myxobolus camerounensis remained the most prevalent.

\section{Prevalence in Relation to Infection Sites and Host}

The prevalence in relation to infection sites and host as shown in Figure 7 reveals that, regardless of the fish species 12 organs were parasitized. O. niloticus and B. callipterus exhibited the highest number of infected organs i.e. 10 and 7 organs respectively. C. gariepinus and H. fasciatus had respectively 3 and 6 parasitized organs. Besides the fact that kidneys were the sole commonly infected organs to all fish species, their infection frequencies were the highest $(\mathrm{P}<$ 0.001 ) whatever the host species.

The prevalence of parasite species as a function of infection sites (Figures 8A, 8B \& 8C and Table 3) illustrates that kidneys harbored $91.67 \%$ of species (11 species over 12 ) in O. niloticus (Table 3), $100 \%$ in B. callipterus (13 species over 13 ) and $75 \%$ (3 species over 4 ) for $H$. fasciatus and $C$. gariepinus. In $H$. fasciatus kidneys (Figure 8A), M. israelensis and $M$. brachysporus were evenly present and five time less prevalent $(\mathrm{P}=0.01)$ than $M$. tilapiae. As for C. gariepinus (Figure 8B), muscles and gall bladder were infected with M. camerounensis and Myxidium petrocephali respectively having the same infection rate (1.19\%). In O. niloticus, kidneys, liver and spleen harbored more parasite species (11; 7 and 4 respectively). Myxobolus kainjiae seemed to be specific to 0 . niloticus ovaries. Moreover, a broad spectrum of target organs was noticed with $M$. camerounensis (6 infected organs over 10 ) with prevalence ranging from 0.86 to $3.14 \%$ in the gills and kidneys respectively. Whatever the parasite species, the prevalence differed significantly from one infection site to another $(\mathrm{P}<0.05)$. Myxobolus tchoumbouei appears to exhibit a broad spectrum of target organs (5 infected organs over 7) in B. callipterus (Figure 8C).

\section{Host Sex Related Prevalence of Myxosporean Infection}

The host sex related prevalence of myxosporean infection as illustrated in Figure 9 reveals that whatever the host species and irrespective of the parasite species, males tended to be more infected than females except in H.fasciatus where males were significantly $(\mathrm{P}=0.001)$ more infected than females. Whether in males or females, the lower prevalence $(\mathrm{P}<0.05)$ was recorded in $H$. fasciatus and $C$. gariepinus.

\section{Prevalence in Relation to Class Size and Correlation between the Prevalence and Fish's Condition Factor (K)}

The prevalence in relation to class size (Figure 10) shows that fishes of all class sizes were infected. In fishes 
whose sizes ranged between 50 and $150 \mathrm{~mm}$, the prevalence was significantly higher in $B$. callipterus and lower in $H$. fasciatus $(\mathrm{P}<0.05)$. In C. gariepinus, the overall prevalence in the class] $200-250]$ was about twice higher $(\mathrm{P}<0.05)$ than that recorded in the class sizes] $100-150]$ and] 150 - 200]. As for $H$. fasciatus; the prevalence was about seven times higher $\left(\mathrm{X}^{2}=12.37 ; \mathrm{P}<0.001\right)$ in the class size 100 $150]$ than size [50-100]. The prevalence was not correlated with the fish size except in $O$. niloticus exhibiting positive and significant correlation $(\mathrm{r}=+0.17 ; \mathrm{P}<0.01)$. Table 2 reveals that whatever the fish species, the prevalence was not correlated $(\mathrm{P}>0.05)$ with the condition factor.

\section{Monthly Related Prevalence as a Function of Fish Species}

No seasonal pattern of host infection (Figure 11) was observed. H. fasciatus and C. gariepinus were found to be infected for 7 and 6 months over 13 months respectively over the 13 months of the sampling period. O. niloticus and $B$. callipterus which were parasitized throughout the 13 months. The infection rate of 0 . niloticus and B. callipterus was higher during July and May 2016 respectively but was lower in the same order in June 2016 and April 2017. As a whole, $H$. fasciatus recorded the lowest prevalence $(\mathrm{P}<$ 0.001 ) during the study period.

\section{Monthly Prevalence of Myxobolus tilapiae in $\boldsymbol{O}$. niloticus}

As earlier illustrated, Myxobolus tilapiae was the most prevalent parasite infecting $O$. niloticus. The latter being appreciated by households and is involved in fish farming program in Cameroon. Figure 12 shows that October 2016 and January 2017 were not favorable to the occurrence of $M$. tilapiae. On the contrary, the highest $(\mathrm{P}<0.05)$ prevalence (34.85\%) was recorded in December 2016.

\section{Discussion}

The diversity of the myxosporeans fauna is in accordance with Combes's [23] assertion as which the pathogenic effects are hardly caused by a single parasite species. The higher prevalence recorded by the genus Myxobolus is documented. In fact, Lom and Diková [18] estimated that the world myxosporeans fauna was composed of about 2180 species gathered within 62 genera among which the genus Myxobolus Bütschli, 1882 represented about 36.33\% of species. This observation is in agreement with the findings of Lekeufack and Fomena [24] who recorded in the River Sangé in Cameroon $54.55 \%$ of myxosporeans of the genus Myxobolus infesting various hosts namely Ctenopoma petherici, Clarias pachynema and Hepsetus odoe. Moreover, Abakar [4] reported in Chad 60\% of Myxobolus species. The same observation was made in Chad By Fomena, et al. [25], then Kostoïngue and Toguebaya [26]; Fall, et al. [27] in Chad, Senegal and Cameroon; Obiekezie and Okaeme [6] in Nigeria.

The genus Myxobolus infected all the four fish species contrary to the genera Myxidium, Henneguya and Thelohanellus. The broad spectrum of hosts observed with Myxobolus spp may be explained by the versatility (flexibility) of its metabolic pathway enabling it to get adapted to various biotopes. In addition, the genus Myxobolus may have a genetic background allowing it to challenge the host immune system. Although the overall prevalence (37.92\%) was low, that may constitute a serious problem to the fish production. Euzet and Pariselle [28] observed that in natural milieu, the pathogenic effects of parasites are reduced because of the balance established during the evolution of host / parasite system. For a given parasite, the infection rate and the status of the parasite species vary geographically [29] according to host species [30]. In farming situation, the overall prevalence can increase because the confinement of fish, the presence of muddy vase, the low oxygenation and low depth of water enhance the transmission of the parasites [6, 31-33].

Irrespective of the parasite species B. callipterus and $O$. niloticus recorded the higher prevalence and harbored about thrice more parasite species than $H$. fasciatus and $C$. gariepinus. The most vulnerable host may either be due to their weak immune system or the intrinsic factors such as the feeding mode. 0 . niloticus for example feeds on algae which are carriers of actinospores. The variation of the number of parasite species per host may be explained by the proximity between fishes and oligochaetes [24] which are definitive hosts $[18,34]$. The scarcity of parasite species in $H$. fasciatus and C. gariepinus should not be incriminated to the competition because according to Sitjà-Bobadilla [35], there is neither inter nor intra specific competition between myxosporeans. Thus, the absence of competition may be at the origin of $O$. niloticus and B. callipterus polyinfection. The specificity of a parasite species to a given taxon may be genetic dependent.

Parasite species which were specific to $O$. niloticus and B. callipterus seemed to be oïoxenous (narrow specificity). Meanwhile, Myxobolus tilapiae and M. brachysporus were stenoxenous to $O$. niloticus and $H$. fasciatus since those parasite species infected hosts belonging to the same family (Cichlidae). O. niloticus and B. callipterus being too distant in the phylogenetic tree, parasite species that were common to them were therefore euryxenous (broad specificity).

Kidneys were the most infected organs probably because, since they filter blood and secrete many solutes [36], parasites converge there for the metabolites they needs. In addition, kidneys and spleen are the initiation 
sites of the developmental cycle for many myxosporean species [31]. Oreochromis niloticus and B. callipterus which recorded the highest percentage of infected organs may have a weak immune system. The specificity of Myxobolus kainjiae to $O$. niloticus ovaries may implies that ovaries provide suitable environment for the $M$. kainjiae survive and also, this latter may be extremely competitive and therefore prevents the establishment of another parasite species. The broad spectrum of target organs observed with M. camerounensis and M. tchoumbouei in O. niloticus and $B$. callipterus respectively may be explained by the versatility of their metabolic pathway enabling them to get adapted to various biotopes. Ibrahim and Soliman [37] thought that the heterogeneity of biotopes generates distinct infection sites which are habitat options for parasites.

The sex did not influence the prevalence regardless of the host and parasite species. This is in agreement with the claims of Abakar [4], Milanin, et al. [38], Lekeufack and Fomena [24]. Fomena [31] didn't find any difference between the infection rate of male and female Oreochromis niloticus at Mélen fish ponds (Yaoundé -Cameroon) by myxosporeans of kidneys and livers. Likewise, Viozzi and Flores [39] noticed that the prevalence of Myxobolus biliare in Galaxias maculates was sex independent and claimed to be the global situation with myxosporidiosis. In $H$. fasciatus and B. callipterus, males were significantly more infected than females because males lose huge amount of energy for testosterone synthesis thus weakening the efficiency of their immune system [40]. Simkova, et al. [41] underlined that the effect of fish sex on the prevalence of myxosporidiosis is not well known.

The infection of fishes of all class sizes was reported by Obiekezie and Okaeme [6] who thought that fishes of all ages are susceptible to myxosporeans infection. Irrespective of the fish species, young hosts were more infected than older ones. This may be due to the small sample size of older fishes (about $30 \%$ of the total population). Tombi and Bilong Bilong [33], Viozzi and Flores [39], Abakar [4] reported that young fishes were more vulnerable to myxosporean infections than older ones. Brummer - Korvenkontio, et al. [30] made the same observation in Finland where the prevalence of infection of Rutilus rutilus by Myxobolus rhodei and M. pseudodispar decreased with the fish age. These authors raised the increase of the immune system response with the size (age) of fish. In contrast to our observation, Nchoutpouen, et al. [42] pointed out that, in farming situation, older Oreochromis niloticus were more infected than the younger ones.

Whatever the fish species, infections occurred during both the rainy season and the dry seasons. Bilong Bilong and Tombi [43], then Abakar [4] also noticed that some myxosporean species were present in fishes throughout the year. The high prevalence observed during the dry season in $O$. niloticus and H. fasciatus can be explained by the high temperature of water and mud encouraging the sinking of actinospores. The latter get aging in the mud and sludge so as to infect $O$. niloticus and $H$. fasciatus feeding on them $[6,44]$. Clarias gariepinus and B. callipterus probably do not feed on mud during the dry season, reason why they exhibit the low infection rate.

\section{Conclusion}

The myxosporean fauna of fishes from the Sudanoguinean zone of Cameroon was diversified. B. callipterus and $O$. niloticus were more infected than C. gariepinus and $H$. fasciatus. Males of $H$. fasciatus were significantly more infected than females. The prevalence of parasite species was not correlated with the condition factor and fish size except that of Myxobolus tilapiae which was positively correlated with 0 . niloticus size. The season did not significantly influence the prevalence. Kidneys were the most infected organ. The recorded data are useful to fish farming and the elaboration of prevention and control strategies against myxosporidiosis.

\section{Conflicts of Interest}

The authors have no conflicts of interest to declare.

\section{References}

1. FAO (2016) The state of world fisheries and aquaculture. Contributing to food security and nutrition for all, pp: 1-200.

2. MINEPIA (2015) Revue sectorielle Aquaculture Cameroun. Ministère de l'Élevage, des Pêches et des Industries Animales (MINEPIA), Yaoundé Cameroun, pp: 44.

3. Renault T, Guichard B (2007) Risk factors for emerging infectious diseases in aquaculture. INRA prod Anim 20(3): 219- 222.

4. Abakar O (2006) Myxosporidia (Myxozoa: Myxosporea) parasites of freshwater fish from Chad: Fauna and biology of species dependent on Oreochromis niloticus (Linné, 1758) and Sarotherodon gallilaeus (Linné, 1758) cichlidae. Thèse de Doctorat d'État. Université de Yaoundé, pp: 169.

5. Longshaw M, Freak PA, Nunn AD, Cowx IG, Feist SW (2010) The influence of parasitism on fish population success. Fish Manage Ecol 17: 246-434.

6. Obiekezie AI, Okaeme AN (1990) Myxosporea (Protozoa) infections of cultured tilapias in Nigeria. J Afr Zool 104: 
77-91.

7. Gbankoto A, Pampoulie C, Marques A, Sakiti GN ( 2001) Occurrence of Myxosporean parasites in gills of tilapia species from Lake Nokoué (Benin, West Africa). Effect of host size and sex, and seasonal pattern of infection. Dis Aqua Organ 44(3): 217-222.

8. Feist SW, Lonshaw M (2005) Myxozoan diseases of fish and effects on host population. Acta zool Sin 51(4): 758760.

9. Olivry JC (1986) Rivers of Cameroon. Paris (FRA), Yaoundé, ORSTOM, MESRES 9: 745.

10. Stiassny MLG, Teugels GG, Hopkins CD (2007) Poissons d'eaux douces et saumâtres de la Basse Guinée, Ouest de l'Afrique Centrale. Collection faune et flore tropicales, Paris I, pp: 797.

11. Charles B, Alan B (1998) Condition Factor, K, for Salmonid Fish. Fisheries Notes.

12. Lizama M, Ambrosio AM (2002) Condition factor in nine species of the Characidae family in the upper Parana river Floodlain, Braz. J boil 62(1): 113-124.

13. Unlu E, Balci K (1993) Observation on the reproduction of Leuciuscephalus orientalis (Cyprinidae) in Savour stream (Turkey). Cybium 17(3): 242- 250.

14. Fulton $\mathrm{T}$ (1902) Rate of growth of seas fishes. Sci Invest Fish Div Scot Rept.

15. Lom J, Arthur JR (1989) A guideline for the preparation of species description in Myxosporea. J Fish Dis 12(2): 151-156.

16. Fomena A, Bouix G (1997) Myxosporea (Protozoa: Myxozoa) of freshwater fishes in Africa: Keys to genera and species.Systematic parasitology 37: 161-178.

17. Lom J, Dyková I (1992) Myxosporidia (phylum Myxozoa). In: Protozoan parasite of fishes developments in aquaculture and fisheries Science, Elsevier, Amsterdam, London, NewYork, Tokyo 26: 159-235.

18. Lom J, Diková I (2006) Myxozoan genera: definition and notes on taxonomy, life-cycle terminology and pathogenic species. Folia Parasitol 53(1): 1 -36.

19. Eiras JC, Molnár K, Lu Y S (2005) Synopsis of the species of Myxobolus Butschli, 1882 (Myxozoa: Myxosporea, Myxobolidae). Systematic Parasitology 61(1): 1-46.

20. Eiras JC, Zhang J, Molnár K (2014) Synopsis of the species of Myxobolus Bütschli, 1982 (Myxozoa: Myxosporea,
Myxobolidae) described between 2005 and 2013. Syst Parasitol 88(1): 11-36.

21. Bush AO, Lafferty KD, Lotz JM, Shostak AW (1997) Parasitology meets ecology on its own terms. J Parasitol 83(4): 575-583.

22. Valtonen ET, Holmes JC, Koskivaara M (1997) Eutrophisation, pollution and fragmentation : effects on parasite communities in roach (Ritilus rutilus) and perch (Perca fluviatilis) in four lakes in Central Finland. Can J Fish Aqua Sci (54): 572-585.

23. Combes C (1995) Interactions durables. Écologie et évolution du parasitisme. Collection d'écologie, $n^{\circ} 26$, Ed. Masson, Paris, pp: 524.

24. Lekeufack Folefack GB, Fomena A (2013) Structure et dynamique des infracommunautés de myxosporidies parasites de Ctenopoma petherici Günther, 1864 (Anabantidae), Clarias pachynema Boulenger, 1903 (Clariidae) et Hepsetus odoe (Bloch, 1794) (Hepsetidae) dans la rivière Sangé au Cameroun. Int J Biol Chem Sci $7(6)$ : 2301-2316.

25. Fomena A, Abakar O, Ngassam P, Bouix G (2004) Description de trois espèces nouvelles de myxosporidies (Myxozoa: Myxosporea) parasites de Citharinus citharinus (Geoffroy Saint-Hilaire, 1809) (Citharinidae) au Tchad (Afrique Centrale). Parasite 11(1): 83-88.

26. Kostoïngue B, Toguebaye BS (1994) Le genre Myxobolus (Myxozoa : Myxosporea) chez les poissons d'eau douce du Tchad avec la description de trois espèces nouvelles. Bulletin de l'I. F.A.N 47: 63-71.

27. Fall M, Fomena A, Kostoïngue B, Diebakate C, Faye N Toguebaye BS (2000) Myxosporidies (Myxozoa, Myxosporea) parasites des poisons Cichlidae du Cameroun, du Sénégal et du Tchad, avec la description de deux nouvelles espèces. Annales des Sciences Naturelles 21(3) : 81-92.

28. Euzet L, Pariselle A (1996) Le parasitisme des poisons siluroidei: un danger pour l'aquaculture ? Aquatic Living resour 9(S1): 145-151.

29. El- Tantawi Sam (1989) Myxosporidian parasites fishes in lakes Dgal Weielki and warniak (Mazurian Lakeland, Poland). I. Survey of parasites. Acta parasitol Polonica 34(3): 203-219.

30. Brummer-Korvenkontio H, Valtonen ET, Pugachev O N (1991) Myxosporea parasites in roach, Rutilus rutilus (Linnaeus) from four Lakes in central Finland. J Fish Biol 38(4): 573-586. 
31. Fomena A (1995) Les Myxosporidies et Microsporidies des poissons d'eau douce du Sud-Cameroun : Étude faunistique, Ultrastructure et Biologie. Thèse de Doctorat d'Etat, Université de Yaoundé, pp: 397.

32. Barassa B, Adriano EA, Arana S, Cordeiro NS (2003) Henneguya curvata sp. n. (Myxosporea; Myxobolidae) parasitizing the gills of Serrasalmus spilopleura (Characidae: Serrasalmidae), South American fresh water fish. Folia Parasitologica 50(2): 151-153.

33. Tombi J, Bilong CF (2004) Distribution of gills parasites of the freshwater fish Barbus martorelli Roman, 1971 (Teleostei: Cyprinidae) and tendency to inverse intensity evolution Between Myxosporidia and Monogenea as a function of the host age. Revue Elev éd Vét Pays trop 57(1-2): 71-76.

34. Kent ML, Andree KB, Bartholomew KL, El-Mattbouli, Desser SS, et al. (2001) Recent advances in our knowledge of the Myxozoa. Journal of Eukaryotic Microbiology 48(4): 395-413.

35. Bobadilla A (2008) Fish immune response to Myxozoan parasites. Parasite 15(3): 420-425.

36. Ellis AE, Robert R J, Tytler P (1978) The anatomy and physiology of teleost. In: Roberts RJ, (Ed.), Fish pathology. BaillièreTindall, London, UK, pp: 3-54.

37. Ibrahim MM, Soliman FMM (2010) Prevalence and site preferences of heterophyid Metacercariae in Tilapia zillii from Ismalia fresh water canal, Egypt. Parasite 17(3): 233-239.
38. Milanin T, Eiras JC, Arana S, Maia AAM, Alves AL, et al. (2010) Phylogeny, ultrastructure, histopathology and parasite of Brycon hilarii (Characidae) in the Pantanal Wetland, Brazil. Mem Inst Oswaldo Cruz, Rio de Janeiro 105(6): 762-769.

39. Viozzi G, Flores V (2003) Myxidium biliare sp.n. (Myxozoa) from gall bladder of Galaxias maculatus (Osmeriformes : galaxidae) in patagonia (Argentina). Folia parasitological 50(3): 90-194.

40. Poulin R (2006) Variation in infection parameters among populations within parasite species: Intrinsic properties versus local. Int J Parasitol 6(8):877-885.

41. Simkova A, Jarkovsky J, Koubkouva B, Barus V, Prokes M (2005) Association between fish reproductive cycle and the dynamics of metazoan parasite infection. Parasitol Res 95(1): 65-72.

42. Nchoutpouen E, Lekeufack Folefack GB, Fomena A (2011) Structure and population dynamics of Myxobolus infections in wild and cultured Oreochromis niloticus Linnaeus, 1758 in the Noun Division (West- Cameroon). J Cell Anim Biol 5(12): 245-264.

43. Bilong Bilong CF, Jeannette Tombi (2004) Hétérogénéité du système branchial de Barbus martorelli roman, 1971 (poisson Cyprinidae) et modèle de croissance. Revue de l'académie des Sciences du Cameroun.

44. Uspenkaya AV (1995) Alternation of actinosporean and myxosporean phases in the life cycle of Zchokklella nova (Myxozoa). J Eukaryot Microbiol 42: 665-668. 